\title{
Diaphragm structure and function in emphysematous hamsters
}

\author{
WD REID BMR (PT) PhD, RK WILTON BSc \\ School of Rehabilitation Sciences and UBC Pulmonary Research Laboratory, \\ University of British Columbia, Vancouver, British Columbia
}

WD REID, RK WILTON. Diaphragm structure and function in emphysematous hamsters. Can Respir J 1994; $1(1): 53-58$.

OBJECTIVE: To determine if muscle fibre injury, reduced force output and fatigue of the diaphragm accompanied hyperinflation induced by experimental emphysema.

DESIGN: Controlled and randomized.

ANIMALS: Adult male golden Syrian hamsters: seven control and seven experimental emphysema hamsters were studied.

INTERVENTIONS: Following anesthesia, experimental imphysema hamsters received a transtracheal injection of elastase. They also received injections of $\beta$-aminopropionitrile every other day for five weeks. After five weeks, all hamsters were anesthetized, and their diaphragm and lumgs wert excised.

MaIN RESults: Measurements of the excised lungs showed an increased residual volume, functional residual capacity and total lung capacity in experimental emphysema hamsters. In vitro physiological study of diaphragm strips showed no difference in force output but a greater fatiguability during repetitive stimulation for $5 \mathrm{mins}$ in experimental emphysema hamsters than in control hamsters. Histological examination did not show significant muscle injury in the diaphragm of experimental emphysema hamsters.

Conclusion: The greater fatiguability and absence of muscle injury in the diaphragm of emphysematous hamsters may result from hyperinflation decreasing diaphragmatic load. Alternatively, muscle damage not detectable at the light microscopic level may have contributed to increased fatiguability of the diaphragm of experimental emphysematous hamsters.

Key Words: Chronic obstructive pulmonary disease. Muscle injury, Respiratory muscles

\section{Structure et fonction diaphragmatiques chez des hamsters emphysémateux}

OBJECTIF : Déterminer si l'atteinte des fibres musculaires. lil diminution du rendement et la fatigue du diaphragme sont assuciées à l'hyperinflation induite par un emphysème expérimental. Monìle: : Contrôlê et randomisé.

Anımaux : Hamsters dorés de Syrie, mâles, adultes: 7 hamsters composant le groupe-témoin et 7 hamsters destinés à développer un emphysème expérimental ont été étudiés.

INTERVENTIONS : Après avoir été anesthésiés, les hamsters du groupe d'emphysème expérimental ont reçu une injection d'élastase par voie transtrachéale puis, des injections de $\beta$-aminopropionitrile tous les deux jours pendant 5 semaines. Après 5 semaines, tous les hamsters ont été anesthésiés puis, leur diaphragme et leurs poumons ont été excisés.

Principaux Résultats : Les mesures des poumons excisés démontraient une augmentation du volume résíduel, de la capacité résiduelle fonctionnelle et de la capacité pulmonaire totale che z les hamsters porteurs d'emphysème expérimental. L'étude physiologique in vitro des bandes diaphragmatiques ne démontrait aucune différence dans le rendement, mais une plus grande fatigue au cours de contractions répétées pendant 5 minutes chez les hamsters emphysémateux que chez les hamsters du groupe-témoín. L'examen histologique ne démontrait aucune atteinte musculaire significative du diaphragme des hamsters porteurs d'emphysème expérimental.

Conclusion : La plus grande fatigue en l'absence d'atteinte musculaire du diaphragme des hamsters emphysémateux pourrait résulter de l'hyperinflation diminuant le travail diaphragmatique. Sinon, une atteinte musculaire non décelable au microscope pourrait avoir contribué à l'augmentation de la fatigue diaphragmatique chez les hamsters du groupe d'emphysème expérimental. 


\section{$\mathrm{C}$} HRONIC OBSTRUCTIVE PULMONARY DISEASE (COPI) IS characterized by increased airway resistance leading to hyperinflation and placement of the inspiratory muscles at shortened lengths, with the diaphragm affected to the greatest degree. Ventilatory loads are increased due both to changes within the lungs and the poor mechanical position of the inspiratory muscles. It has been previously proposed that factors that increase the loads and/or decrease energy supplies could contribute to chronic respiratory muscle fatigue in patients with COPD (I). However, more recent evidence appears to support at second hypothesis that some COPD patients may have weak rather than fatigued respiratory muscles (2). The present study postulated that if the loading is severe, muscle injury of the diaphragm occurs.

An animal model of increased resistive loading by tracheal banding hamsters was developed and marked diaphragm damage and inflammation were found (3). Another animal model, experimental emphysema, leads to profound hyperinflation and flattening of the diaphragm (4) but little change in pulmonary resistance (5). In experimental emphysema, the ventilatory loads imposed on the diaphragm may he greater because it is forced to pump more frequently in a less functional position. Alternatively, a less functional position of the diaphragm may result in decreased recruitment of this muscle and greater reliance on other inspiratory muscles for ventilation. The purpose of this study was to determine if muscle fibre injury, reduced force output and fatigue of the diaphragm accompanied hyperinflation induced by experimental emphysema. The effects of this type of loading on the diaphragm were assessed by examining: first, muscle morphology using light microscopy; and second, in vitro physiological function of costal diaphragm strips.

\section{METHODS}

\section{Animals and groups}

Fourteen adult male golden Syrian hamsters were obtained from Charles River and cared for in accordance with the principles outlined in Care for Experimental Animals: A Guide for Cancada (Canadian Council on Animal Care 1980 and 1984). Two groups of animals ( 16 to 19 weeks old) were studied: seven control (C) and seven experimental emphysemat (E) hamsters. Their mean body weight was $138 \pm 20 \mathrm{~g}$.

\section{Experimental protocol}

The experimental protocol received ethical approval from the University of British Columbia Animal Care Committee. Following premedication with atropine and diazepam, hamsters were anesthetized by intraperitoneal injection of sodium pentobarbital $(6.5 \mathrm{mg} / 100 \mathrm{~g}$ body weight $)$. A small incision was made over the trachea, and the tissues overlying the trachea were bluntly dissected in order to view the trachea. The animal was placed on a $45^{\circ}$ angle and 25 units of porcine pancreatic elastase (Sigma, Missouri) per $100 \mathrm{~g}$ body weight diluted in $0.3 \mathrm{~mL}$ of saline solution was injected transtracheally into the lungs of the E group. A similar amount of saline was injected transtracheally into the lungs of the $\mathrm{C}$ group. Hamsters recovered from the anesthesia. Immediatcly after the transtracheal injections of elastase or saline only, each animal was rotated side to side to facilitate distribution of solutions throughout the animal's lungs.

All hamsters were monitored daily and $\mathrm{E}$ hamsters received intraperitoneal injections of $\beta$-aminopropionitrile monofumurate (Sigma) (1 mg/g body weight), a lathyrogen that interferes with elastin synthesis (6), every other day during the next five weeks. Four-and-a-half weeks after the transtracheal injection of elastase, four $E$ hamsters had their left carotid artery chronically cannulated (3). Five weeks after the transtracheal injection of elastase, hamsters were again anesthetized with an intraperitoneal injection of sodium pentobarbital. Under deep anesthesia, the great vessels were transected and the diaphragm was excised with the left anterior rib cage left attached. A strip of muscle from the left anterior costal diaphragm was excised to determine in vitro physiological function. Biopsies from the right costal diaphragm were cut and quick frozen in isopentane cooled to the temperature of liquid nitrogen for histochemical analysis. Frozen tissue was stored at $-70^{\circ} \mathrm{C}$ until processing. Lung volumes were determined from the excised lungs.

Lung volumes: Just before sacrificing the hamster by transection of the great vessels, the trachea was tied off at functional residual capacity (FRC). After removal of the muscle biopsies, the lungs and mediastinum were removed. FRC was determined by volume displacement of the lungs in saline. To determine residual volume ( $\mathrm{RV}$ ), the tie on the trachea was removed, the lungs were deflated to at least $-20 \mathrm{cmH}_{2} \mathrm{O}$, and the lung volume was determined by volume displacement in saline. Lastly, total lung capacity (TLC) was determined by formalin fixation at $30 \mathrm{cmH}_{2} \mathrm{O}$. The weight of the mediastinum and lungs was subtracted from the volumes determined.

In vitro physiological function: Under a dissecting microscope, a $2 \mathrm{~mm}$ wide strip of the costal diaphragm was excised with its attachments to the central tendon and a small segment of the rib cage. The muscle was quickly placed into a jacketed muscle bath containing Kreb's solution (115 mM sodium chloride, $25 \mathrm{mM}$ sodium bicarbonate, $1.2 \mathrm{mM}$ sodium phosphate monobasic, $5.0 \mathrm{mM}$ potassium chloride, $3.4 \mathrm{mM}$ calcium chloride, $1.2 \mathrm{mM}$ magnesium sulphate and $2 \mathrm{~g}$ D glucose/L) held at $37^{\circ} \mathrm{C}$ and bubbled with $95 \%$ oxygen and $5 \%$ carbon dioxide. The muscle strip was mounted horizontally between a motor arm using a small stainless steel clip attached to the central tendon and a force transducer $( \pm 50 \mathrm{~g}$, Kulite) using a silk suture tied around the rib segment. The strips of muscle were electrically stimulated via platinum plate electrodes. Optimal length $\left(\mathrm{L}_{0}\right)$ was defined as the length at which maximal twitch tension $(0.2 \mathrm{~ms}$ duration) developed. All subsequent contractions were performed at $\mathrm{L}_{0}$. Isometric tension output during variable frequencies ( 1 , $20,30,50$ and $100 \mathrm{~Hz}$ ) were determined. The diaphragmatic muscle strip, held at $\mathrm{L}_{0}$, was then exposed to a fatigue run of repetitive bursts of electrical stimuli (duty cycle: $0.20,30 \mathrm{~Hz}$, repetitions: $24 / \mathrm{min}$ ) for $5 \mathrm{mins}$. The percentage force loss during the fatigue run was calculated. Next, the muscle was 


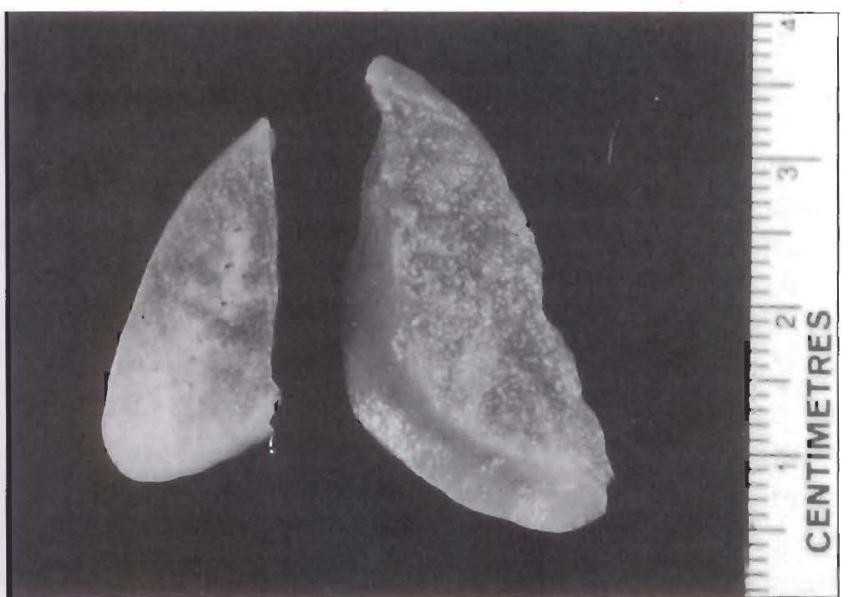

Figure 1) Sagittal section of left lower lobe from control (left) and emphysematous (right) hamsters. Note the increased size of the left lobe from the emphysematous hamster. In addition, the cut surfac' shows increased porosity, which is a reflection of the larger size of the airspaces in the emphysematous lung

blotted dry, the rib cage and central tendon were removed, the muscle strip was weighed, and the cross-sectional area was determined using the technique by Close et al (7). Force output was expressed per cross-sectional area (specific force).

\section{Histological analysis}

Cross-sections of costal biopsies were cut $10 \mu \mathrm{m}$ thick on a cryostat-microtome (Reichart-Jung, New York) and stained with hematoxylin and eosin. The area fractions $\left(A_{A}\right)(8)$ of normal muscle, abnormal and inflamed muscle, and connective tissue were determined from cross-sections of each biopsy. AA were determined using a light microscope equipped with a camera lucida (Libophot, Nikon, Japan) and a computer program for point counting that was developed in this laboratory. The image of at 50-point grid from the computer monitor was projected wia the camera lucida onto the field of view of the diaphragm cross-sections viewed at 400x. The points projected on the cross-section were then assigned to one of the following categories: I, normal muscle; 2, abnormal and inflamed muscle including necrotic muscle, viable muscle with abnormal morphology, necrotic muscle with inflammatory cells, inflammatory cells (where no outline of a muscle cell was evident) and effusion; 3, connective tissue - fat or collagen; 4, no count - if the point fell onto clear space, nerve or vessels. The number of points in each of the first three categories was divided by the total number of points in these three categories to determine $\mathrm{A}_{\mathrm{A}}$.

\section{Statistical analysis}

Multivariatte analyses using Hotelling $\mathrm{T}^{2}$ tests (Systat, Inc, Illinois) examining for differences between $\mathrm{C}$ and $\mathrm{E}$ hamsters were performed on groups of related parameters: first, presence of muscle injury $\left(\mathrm{A}_{\mathrm{A}}\right.$ of normal, abnormal and inflamed muscle); second, lung volumes (RV, FRC, TLC); third, forco output at low frequency $(1,20$ and $30 \mathrm{~Hz})$ and high frequency

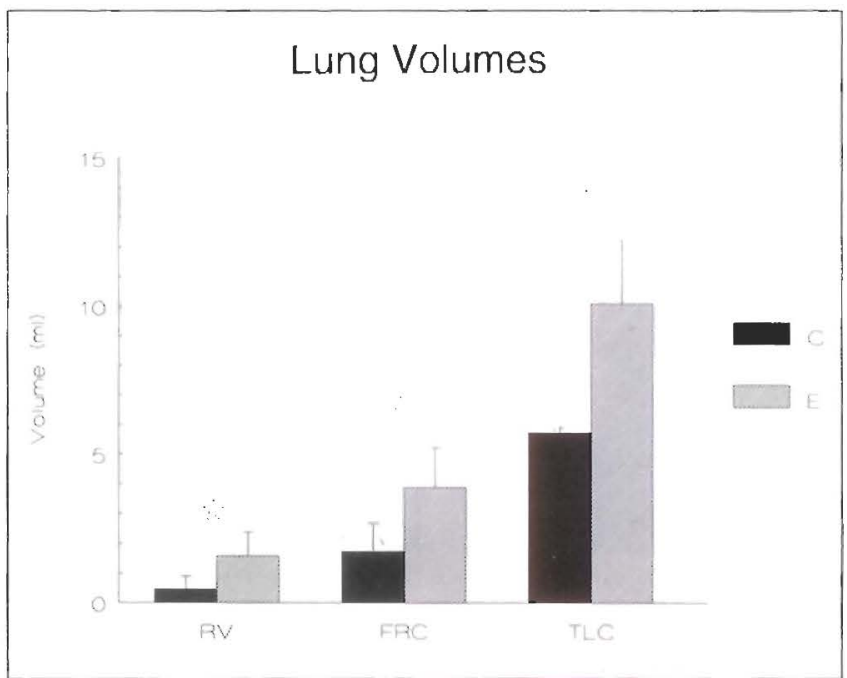

Figure 2) Bar plot of lung volume's in control and emphysematous hamsters. Mean \pm standard deviation. Stars indicate significance hotween groups at $P<0.05$. C Control; E Experimental emphysena; FRC Functional resided capacity; RV Residual volume; ThC Total lung copacity

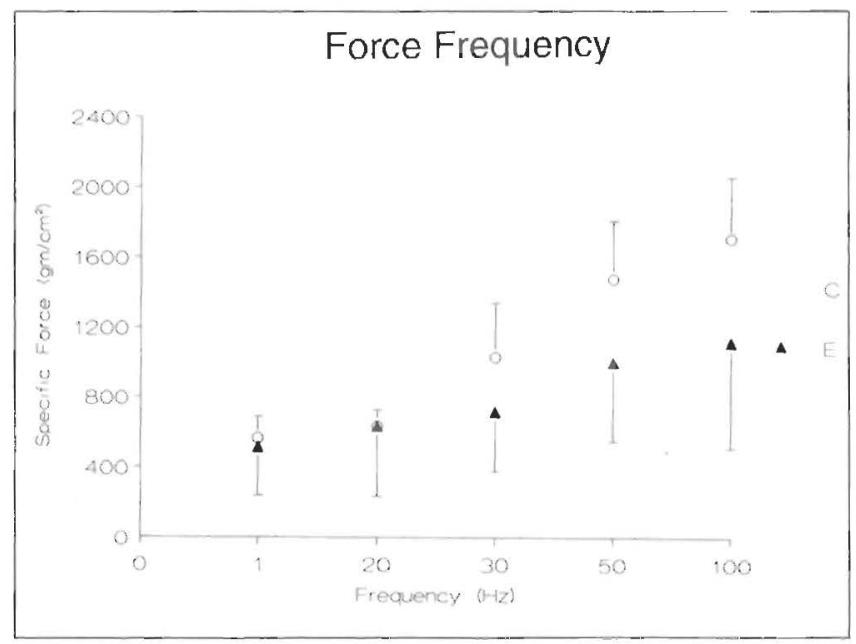

Figure 3) Plot of specific force over a range of stimulation frequencies. Mean \pm standard deviation. C Control; E Experimental emplysema

(50) and $100 \mathrm{~Hz}$ ) stimulation; and fourth. fatiguability (force drop during repetitive stimulation). If the multivariate analy. sis indicated a significant difference in a group of related parameters between the $\mathrm{C}$ and $\mathrm{E}$ hamsters, Student's $t$ tests were performed on individual parameters to look for specific differences between $\mathrm{C}$ and $\mathrm{E}$ hamsters.

Differences were accepted as being significant at $\mathrm{P}<0.05$.

\section{RESULTS}

$\mathrm{E}$ hamsters had increased lung volumes compared with those values in $\mathrm{C}$ hamsters (Figures 1 and 2). RV was $1.57 \pm 0.82 \mathrm{~mL}$ in the $\mathrm{E}$ hamsters versus $0.47 \pm 0.44$ in the $\mathrm{C}$ hamsters $(\mathrm{P}<0.05)$. FRC was $3.88 \pm 1.34 \mathrm{~mL}$ in the $\mathrm{E}$ hamsters versus $1.74 \pm 0.93$ in the $C$ hamsters $(P<0.05)$. TLC was $10.10 \pm 2.39 \mathrm{~mL}$ in the $\mathrm{E}$ hamsters versus $5.74 \pm 1.26$ in the $\mathrm{C}$ 


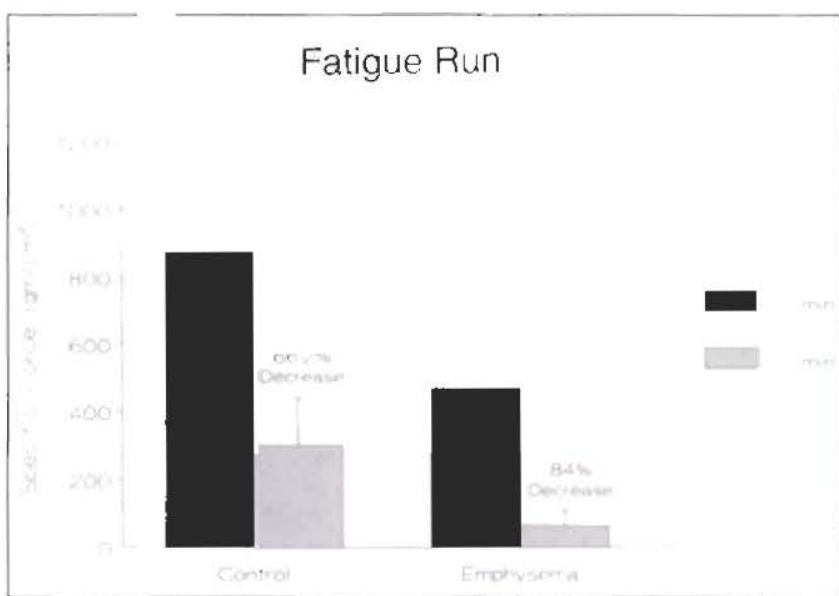

Figure 4) Bar plot of specific force at 0 and 5 mins of the fatigue run of repetitive electrical stimulation. Mean \pm standard deviation. Difference in percentage force drop between two groups is significant at $P<0.05$

TABLE 1

Area fractions of normal and abnormal diaphragm

\begin{tabular}{lccc}
\hline Group & $\begin{array}{c}\text { Normal } \\
\text { muscle }\end{array}$ & $\begin{array}{c}\text { Abnormal muscie } \\
\text { and inflammatory } \\
\text { cells }\end{array}$ & $\begin{array}{c}\text { Connective } \\
\text { tissue }\end{array}$ \\
Control & & & \\
Mean & 0.905 & 0.031 & 0.064 \\
Standard error & 0.033 & 0.026 & 0.026 \\
Experimental emphysema & & \\
Mean & 0.893 & 0.046 & 0.063 \\
Standard error & 0.028 & 0.035 & 0.013 \\
\hline
\end{tabular}

hamsters $(\mathrm{P}<0.05)$. Arterial blood gases in four $\mathrm{E}$ hamsters tended towards a respiratory acidosis and hypoxemia $(P C O 2$, $62.8 \pm 5.7 \mathrm{mmHg} ; P O 2,60.6 \pm 8.9 \mathrm{mmHg} ; \mathrm{pH}, 7.32$; bicarbonate, $27.4 \pm 10.4 \mathrm{mmol} / \mathrm{L}$ ) relative to control values obtained in another study performed in the authors' laboratory (3); however, arterial blood gases were not determined in enough animals to determine statistical significance.

There was no difference in force output of diaphragm muscle strips over a range of stimulation frequencies between $\mathrm{E}$ and $\mathrm{C}$ hamsters (Figure 3 ). Specific force values at the lowest frequencies of stimulation were very similar: twitch stimulation showed $514 \pm 276 \mathrm{~g} / \mathrm{cm}^{2}$ for E hamsters versus $565 \pm 123 \mathrm{~g} / \mathrm{cm}^{2}$ for $\mathrm{C}$ hamsters, and stimulation at 20 Hz showed $635 \pm 401 \mathrm{~g} / \mathrm{cm}^{2}$ for E hamsters versus $634 \pm 94$ $\mathrm{g} / \mathrm{cm}^{2}$ for $\mathrm{C}$ hamsters. Specific force at the higher frequencies of stimulation tended towards being lower in E hamsters. although there were no statistical differences between $\mathrm{E}$ and C hamsters: $30 \mathrm{~Hz}$ stimulation showed $718 \pm 340 \mathrm{~g} / \mathrm{cm}^{2}$ for E hamsters versus $1032 \pm 310 \mathrm{~g} / \mathrm{cm}^{2}$ for $\mathrm{C}$ hamsters, stimulation at $50 \mathrm{~Hz}$ showed $1004 \pm 454 \mathrm{~g} / \mathrm{cm}^{2}$ for E hamsters versus $1481 \pm 335 \mathrm{~g} / \mathrm{cm}^{2}$ for $\mathrm{C}$ hamsters, and stimulation at $100 \mathrm{~Hz}$ showed $1118 \pm 606 \mathrm{~g} / \mathrm{cm}^{2}$ for $\mathrm{E}$ hamsters versus $1714 \pm 353$ $\mathrm{g} / \mathrm{cm}^{2}$ for $\mathrm{C}$ hamsters. Optimal length did not differ between $\mathrm{E}$ and $\mathrm{C}$ hamsters ( $13.5 \pm 1.3$ versus $13.2 \pm 1.5 \mathrm{~mm}$ ).

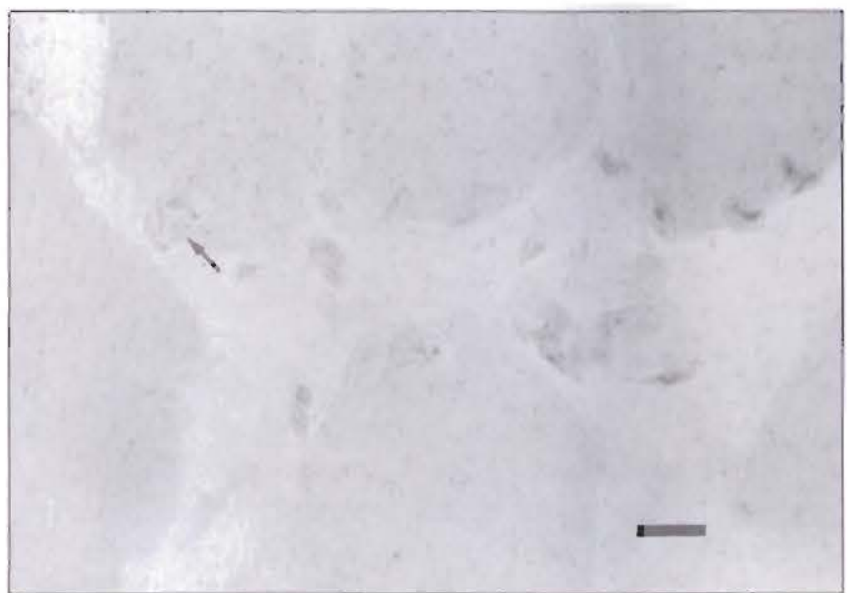

Figure 5) Cross-section of costal diaphragm from experimental emphysema hamster stained with hematoxylin and eosin. Note the internal nuclei, flocculent degeneration of the cytoplasm and influx of inflammatory cells. Arrow is pointing to a neutrophil. Scale: Bar $=8 \mu \mathrm{m}$

There was a greater loss in force during repetitive fatiguing stimulations for 5 mins in $\mathrm{E}$ hamsters than in $\mathrm{C}$ hamsters $(\mathrm{P}<0.05)$ (Figure 4). Although some biopsies showed evidence of muscle injury and inflammation (Figure 5), quantitative analysis of muscle injury and inflammation in the diaphragm showed no difference between $\mathrm{C}$ and $\mathrm{E}$ hansicrs (Table I).

\section{DISCUSSION}

Emphysematous hamsters demonstrated marked hyperinflation associated with increased in vitro fatiguability of the diaphragm. In contrast to a model of increased resistive loading (3), we found no significant evidence of diaphragm muscle injury and inflammation in emphysematous hamsters.

The profound hyperinflation in emphysematous hamsters results in marked flattening of the hamster diaphragm as shown on X-ray (4). The diaphragms in the emphysematous hamsters of this study may have been placed in a similar flattened, less functional position. This may have resulted in decreased recruitment of the diaphragm and greater reliance on other primary and accessory inspiratory muscles for inspiration. Alternatively, the mechanical disadvantage of the diaphragm in a more flattened position may have forced this muscle to work harder and possibly resulted in muscle injury not detectable by our techniques at the light microscopic level. Either decreased use of the diaphragm or undetected damage, such as disorganization of the myofibrillar structure (3). could explain the increased fatiguability of the diaphragm in our study. A third possibility is that decreased elastin, due to administration of $\beta$-aminopropionitrile, in the various connective tissue layers surrounding individual muscle fibres and myofibrils resulted in increased fatiguability of the costal strips from the E hansters. However, there is little information in the literature to support or refute this hypothesis. 
Our results differ from those of others regarding the in vitro fatiguability of costal diaphragm strips from $\mathrm{E}$ hamsters. However, very different stimulation regimens were used in previous studies, so it is very difficult to compare the results. Both Farkas et al (9) and Lewis et al (10) found that costal strips from $E$ hamsters were less fatiguable than those from $C$ hamsters. The protocols in both of the previous studies were more rigorous than our protocol, using a higher duty cycle $(0.33$ to 0.38 versus 0.20 in our study) and a higher repetition rate ( 60 to 90 repetitions/min versus 24 repetitions/min in our study). It is quite possible that different processes such as high energy phosphate depletion and proton load contributed to fatigue in the more rigorous protocols used previously, whereas the glycogen depletion or ionic imbalance may have contributed to fatigue in our less stressful protocol. Little work has been done to investigate mechanisms contributing to fatigue in different stimulation paradigms used for in vitro fatiguc protocols. We selected to use the stimulation protocol previously outlined by Pagala et al (11) because it appeared to be the least stressful protocol relative to others in the literaturc.

Another factor that may have contributed to the differing fatiguability results between previous studies $(9,10)$ and our study was duration for which experimental emphysema was imposed. In previous reports by Farkas et al (9) and Lewis et al (10), the duration of emphysema was approximately six months, compared with five weeks in our study. The Ionger duration of emphysema in previous studies would have provided a much longer time period for completion of any adaptive process in the diaphragm. We chose to study the diaphragm after shorter duration of emphysema for that very reason. Hyperinflation had been previously reported after five weeks of inducing emphysema (5). If diaphragm injury occurred, however, it was less likely that reparative processes would be complete relative to a six-month period of emphysema.

There was no loss of force output at low or high frequencies of stimulation in $\mathrm{E}$ hamsters. Specific force is related to muscle fibre type composition (12) and the cross-sectional area composed of viable muscle. It is unlikely that the fibre type composition of the diaphragm was changed by hyperinflation induced over the five-week period that emphysema was produced in this study, because three previous studies examining the effects of much longer periods of experimental emphysema on the hamster diaphragm found no differences in fibre type proportions $(9,10,13)$. Regarding cross-sectional area of viable muscle, we did not find a significant increase in $A_{A}$ of muscle fibre damage although abnormalities were seen in the diaphragm of some hamsters.

The lack of change in force output in our study is similar to results from two early studies that showed a similar specific tension of costal diaphragm strips from control and emphysematous hamsters stimulated in vitro $(14,15)$. In contrast, a more recent study by Lewis et al (10) found that the specific force of the diaphragm decreased in emphysematous hamsters. In all of the previous studics $(10,14,15)$, emphysema was induced for Ionger (six to 18 months) than the five-week period in our study before diaphragm function was studied. Emphysema was induced in seven- to nine-week-old animals for six months in the study by Lewis et al (10), and in 40-week-old animals for 23 weeks in the study by Farkas and Roussos (14). Supinski and Kelsen (15) did not describe the age of their animals, but emphysema was induced for 18 months before study of the diaphragm. The younger animals used in the study by Lewis et al (I0) may have enabled at greater transformation of muscle characteristics including myosin isozymes during the animals' development and, hence, a difference in specific force output.

We did not find any significant differences in the proportions of normal muscle, abnormal muscle and connective tissue in the cross-sectional area of the costal diaphragm. Other investigators have found that, although experimental emphysema produces profound hyperinflation, there is little change in pulmonary resistance in hamsters (5) in contrast to the 6.5 -fold increased pulmonary resistance in the six-dily tracheal banding model (16). The overall work of breathing imposed on the diaphragm is likely much less in the emphysematous model relative to the six-day tracheal banded model because of hyperinflation flattening the diaphragm and the small change in pulmonary resistance. In addition, due to the time course of experimental emphysema, the work of breathing would change much more gradually than that of tracheal banding. Thus, the workload imposed may have been insufficient and/or too gradual to cause any consistent amount of diaphragm injury, although muscle damage was observed in some animals. It is possible, however, that excessive loading was imposed on the other inspiratory muscles leading to overuse injury; however, we did not examine other inspiratory muscles in this study.

In conclusion, hyperinflation resulting from experimental emphysema in hamsters does not induce significant muscle injury in the diaphragm shown at the light microscopic level. Increased fatiguability of the diaphragm in emphysematous hamsters may result from hyperinflation decreasing diaphragmatic load. Alternatively, muscle damage not detectable at the light microscopic level may have contributed to increased fatiguability of the diaphragm of $\mathrm{E}$ hamsters.

ACKNOWLEDGEMENTS: We acknowledge the assistance of Mr Frank Chung for statistical analysis. We are grateful to the British Columbia Lung Association and BC Health Research Foundation for funding to support this project. Dr W Darlene Reid was funded by a Scholar Award from the British Columbia Health Research Foundation during completion of this project.

\section{REFERENCES}

I. Roussos C. Ventilatory failure and respiratory muscles. In: Roussos C, Macklem PT, eds. The Thorax. Part B. Lung Biology in Health and Disease, vol 29. New York: Marcel Dekker, 1985:1253-79.

2. Rochester DF. Respiratory muscle weakness, pattern of breathing and $\mathrm{CO}_{2}$ retention in chronic obstructive pulmonary disease. Am Rev Respir Dis 1991;143:901-3.

3. Reid WD, Huang J, Bryson S, Belcastro AN. Diaphragm. muscle injury and myofibrillar structure induced by resistive loading. J Appl Physiol 1994;76:176-84. 
4. Snider GL, Sherter CB. A one-year study of the evolution of clastase-induced emphysema in hamsters. J Appl Physiol 1977;43:721-9.

5. Oliven A, Supinski GS, Kelsen SG. Functional adaptation of the diaphragm to chronic hyperinflation in emphysematous hamsters. J Appl Physiol 1986;60:225-31.

6. Kuhn C III, Starcher BC. The effect of lathyrogens on the evolution of elastase-indeced emphysena. Am Rev Respir Dis 1980;122:453-9.

7. Close RI. Dynamic properties of mammalian skeletal muscles. Physiol Rev 1972;52:192-7.

8. Cruz-Orive LM, Weibel ER. Recent stereological methods for cell biology. Am J Physiol 1990;258:Li 48-57.

9. Farkas GA, Roussos C. Adaptability of the hamster diaphragm to exercise and/or emphysema. J Appl Physiol 1982;53:1263-72.

10. Lewis MI, Zhan W-H, Sicck GC. Adaptations of the diaphragm in emphysema. J Appl Physiol 1992;72:934-43.
11. Pagala MKD, Namba T, Grob D. Failure of neuromuscular transmission and contractility during muscle fatigue. Muscle Nerve 1984;7:454-64.

12. Eddinger TJ, Moss RL. Mechanical properties of single skinned fibres of identified types from rat diaphragm. Am J Physiol 1987;253(Cell Physiol 22):C210-8.

13. Kelsen SG, Wolanski T, Supinski GS, Roessmann U. The effect of elastase-induced emphysema on diaphragm muscle structure in hamsters. Am Rev Respir Dis 1983;127:33()-4.

14. Farkas GA, Roussos C. Diaphragm in emphysematous hamsters: Sarcomere adaptability. J Appl Physiol 1983:54:1635-40.

15. Supinski GS, Kelsen SG. Effect of elastase-induced emphysema on the force-generating ability of the diaphragm. J Clin Invest 1982;70:978-88.

16. Reid WD, Noonan J, Chung F, Tesler-Mabe C. Ventilatory failure induced by tracheal banding in the hamsters. J Appl Physiol 1992;73:1671-5. 


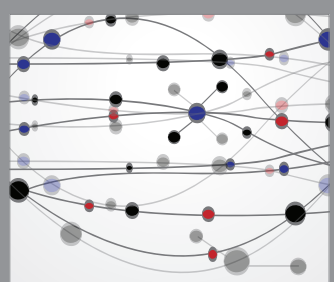

The Scientific World Journal
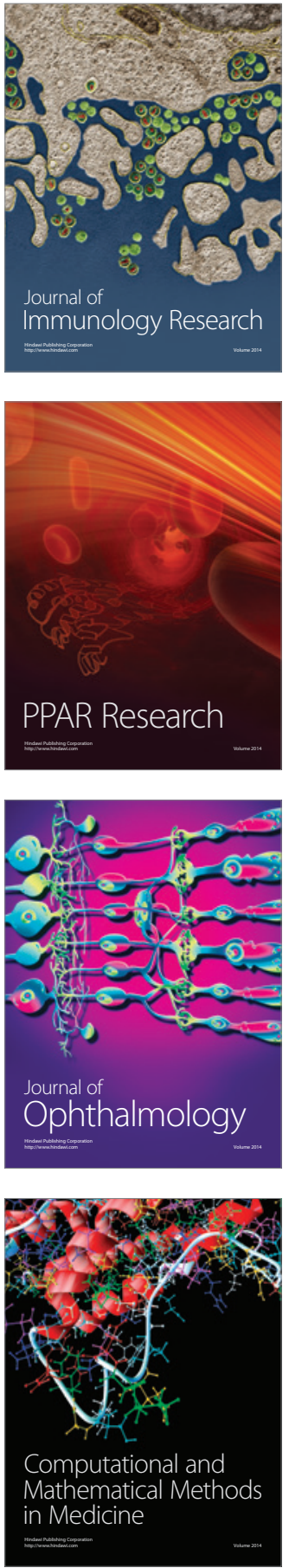

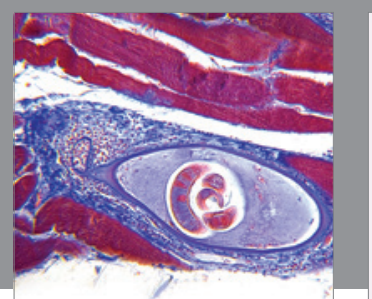

Gastroenterology Research and Practice

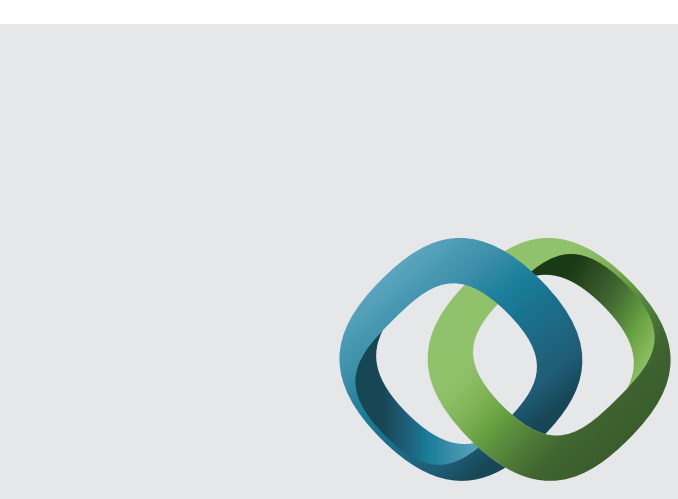

\section{Hindawi}

Submit your manuscripts at

http://www.hindawi.com
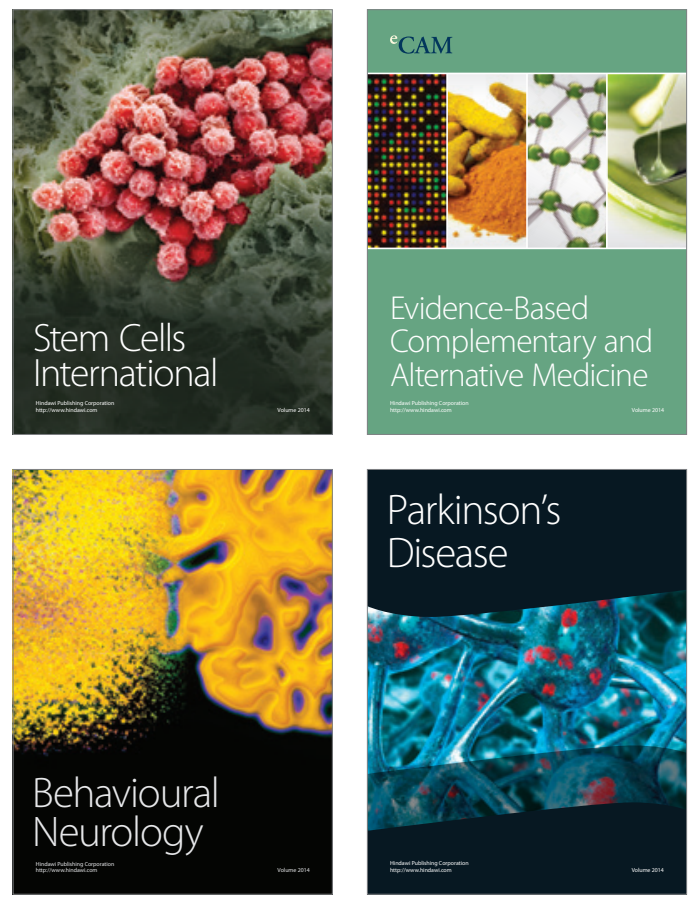
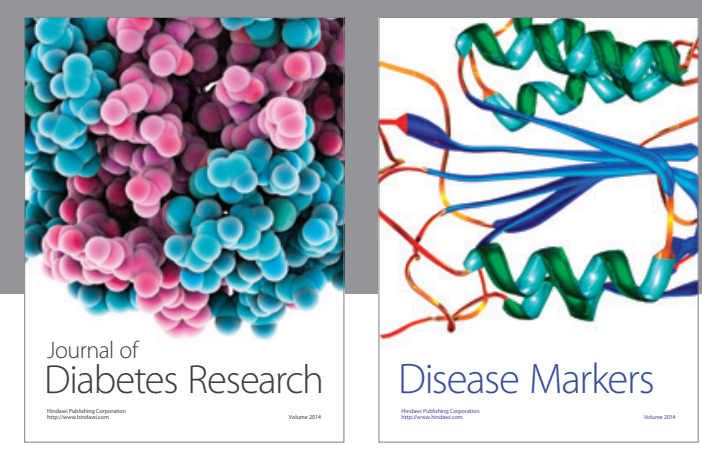

Disease Markers
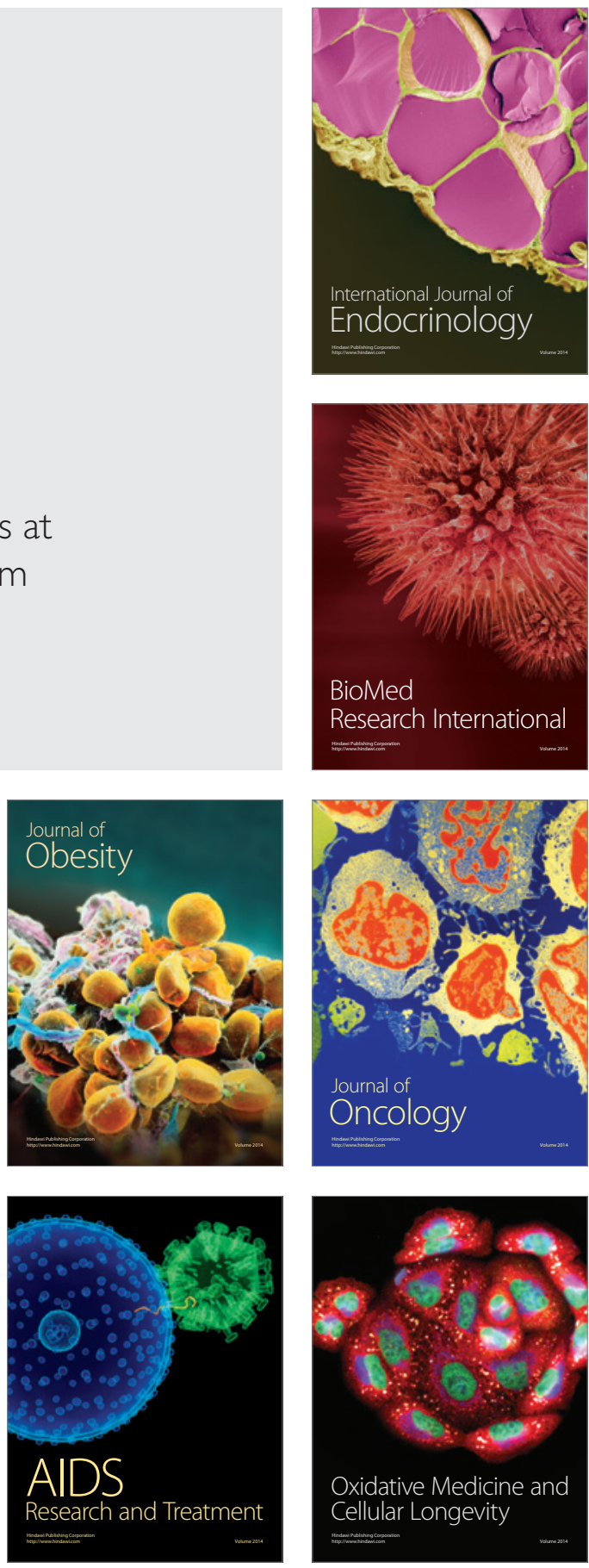